\title{
Research Paper \\ Using the Backman Model in Determining the Dimensions of Self-Care and Its Factors Affecting the Elderly in Tehran City, Iran
}

\author{
Leili Salehi ${ }^{1}$ (), * Leila Keikavoosi-Arani² ${ }^{\circledR[}$
}

1. Department of Promotion and Education, Research Center for Health, Safety and Environment, School of Health, Alborz University of Medical Sciences, Karaj, Iran 2. Department of Healthcare Services Management, Research Center for Health, Safety and Environment, School of Health, Alborz University of Medical Sciences, Karaj, Iran.

$\begin{gathered}\text { Use your devic to scan } \\ \text { and read the article online }\end{gathered}$
Affecting the Elderly in Tehran City, Iran (Persian)]. Quarterly of "The Horizon of Medical Sciences". 2020; 26(4):382-397. https://
doi.org/10.32598/hms.26.4.3251.1
doi https://doi.org/10.32598/hms.26.4.3251.1

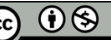

Received: 11 Sep 2019 Accepted: 22 Jun 2019 Available Online: 01 Oct 2020

Key words: Self Care, Elderly, Backman Model

\section{A B STRACT}

Self-care helps older people manage their own health and stay independent by delaying disability. This study aimed to apply the Backman Model in determining the dimensions of self-care and the factors affecting it in the elderly in Tehran.

Methods \& Materials This cross-sectional study was performed on 400 elderly members ofnursing homes by systematic random sampling. Data gathering tool included demographic characteristics and self-care behaviors, self-care orientation, life satisfaction assessment, self-confidence, social support, and functional capability. The Chi-square and Pearson correlationand regression analysis were used with a significance coefficient of 0.05. The data were analyzed in SPSS v. 19.

Findings The total mean ages of elderly were $69.11 \pm 7.51,42.5 \%$ male. There was significant difference between the types of self-care and gender only in the dimensions of work habits $(P<0.001)$ and medical treatment $(P<0.001)$. Pearson correlation indicated there was a direct and positive relationship between self-care type and self-care orientation $(r=0.662, P=0.01)$. The relationship between self-care type and social support was negative ( $r=0.075, P=0.01)$.

Conclusion Factors such as life satisfaction, functional capacity, social support and self-confidence are associated with self-care in the elderly. It is suggested that health system policymakers formulate support programs for the elderly in various forms, such as the elderly access to transportation program, facilities, tax exemptions, etc.

\section{English Version}

\section{Introduction}

elf-care includes activities that human beings perform specifically for survival, healthy functioning, continuous improvement, and feeling well [1]. By the aging of the world's population and the increasing prevalence of chronic diseases in the elderly [2], the importance of self-care and health-promoting behaviors is increasing day by day, regarding the maintenance of function, independence of individuals, and increasing their quality of life [3]. Self-care helps the elderly to manage their health and stay independent [4]. Self-care is one

도.

* Corresponding Author:

Leila Keikavoosi-Arani, PhD.

Address: Department of Healthcare Services Management, Research Center for Health, Safety and Environment, School of Health, Alborz University of Medical Sciences, Karaj, Iran.

Tel: +98 (26) 3464355

E-mail: leila_keikavoosi@yahoo.com 
of the main factors in the life of an elderly person in his own home, which is affected by many factors [5]. As people get older, they need more time to recover from the disease, which in turn affects their ability and motivation to take care of themselves [6].

Research shows that self-care in the elderly is directly related to factors such as education level, socio-economic status, and social support and is inversely related to stressful life events. The elderly people, people with low socioeconomic status, and minority groups need special attention in terms of self-care $[7,5]$. These people are at the lowest level of health, have the minimum activity in self-care, and the least self-confidence in knowing and understanding how to take care of themselves. Self-efficacy improves self-care practices and reduces chronic disabilities [8]. Various studies have shown that elderly self-care is associated with several factors such as life satisfaction, self-esteem, functional capability, level of education, family reaction, and support from the family [9-12].

Tracy et al. in a study entitled "Outcome Clinic: An Innovative International Primary Care Model for the Elderly With Complex Health Care Needs" showed that the frequency of disability and its effects on living conditions are two important determinants of quality of life in the elderly [5].

Today, with the increase in the average life expectancy, the distribution of the elderly population worldwide has significantly changed [13], so that the fastest population growth is related to the elderly [14]. In this regard, it is predicted that the elderly population will reach two billion people by 2050 . In Iran, according to the Statistics Center, the elderly population will grow to 10 million by 2019 [15]. Aging is one of the most important social developments of the $21^{\text {st }}$ century and its consequences affect all sectors of society, including the labor market, demand for goods and services such as housing, transportation, social support, and intergenerational relations [16]. In Iran between 1956 and 2016, over a period of six decades the population aged 65 and over increased 542\% (about 9\% per year) [17].

Today, about 4500000 elderly people live in Iran. According to the National Census of Iran in 2016, about $8.5 \%$ of the total population of the country and more than $7.5 \%$ of Tehran City is over 65 years old. Given the current demographic structure, the unpredictable aging population trend in the coming years, from $7.27 \%$ in 2006 to more than $16 \%$ in 2050 , is predicted to be a phenomenon that has never occurred before [18]. Old age does not mean disability, and providing self-management and self-care programs to control chronic illness to the elderly can prevent and even delay disability in people with chronic illnesses such as arthritis, heart disease, or high blood pressure. Given the undeniable and key effects of self-care on aging with health, conducting more studies to promote self-care is one of the provisions of the health sector. Therefore, this study was performed using the Backman model in determining the dimensions of self-care and the factors affecting it in the elderly in Tehran City. This model is a systematic and integrated model that clarifies the self-care knowledge of the elderly.

\section{Materials and Methods}

This cross-sectional (descriptive-analytical) study was performed on 400 elderly members of 10 nursing homes in Tehran City. These ten homes were randomly selected among the elderly centers in Tehran City. Then, according to the number of elderly people in each home, they were examined and the subjects were systematically identified among the homes. The inclusion criteria were as follows: age over 60 years, speaking Persian, no hearing impairment or mental problems, and a desire to participate in the study. Assuming that $50 \%$ of the elderly had self-care, the sample size was determined to be about 385 with $80 \%$ power and $95 \%$ confidence level. Five questionnaires of self-care behaviors including self-care orientation, life satisfaction assessment, self-confidence, social support, and functional capability were used. At the beginning of the questionnaire, demographic characteristics of the elderly such as age, gender, occupation, lifestyle, and marital status were considered.

Elderly self-care behaviors were assessed by a self-care questionnaire that included 42 questions and 12 dimensions of awareness and willingness to self-care (4 questions), physical condition (5 questions), communication with health care staff (5 questions), communication with family (3 questions), meaningful and stimulating aging ( 3 questions), understanding the future (3 questions), treatment and medication management (2 questions), work habits (6 questions), past events (3 questions), confidence and trust (2 questions), medical treatment (2 questions), and future perspectives (4 questions). Scoring questions based on the 5-point Likert scale ranged from "strongly disagree" (score 1) to "strongly agree" (score 5). A higher score in this questionnaire indicated good status and a low score indicated a bad status. This tool was first designed by Backman and Hentinen based on their model [19].

The tendency to self-care was assessed based on a 14-item questionnaire by Backman and Hentinen (2001). The questions were scored on a 5-point Likert-type scale (strongly in favor of $=5$ to strongly opposed to $=1$ ). A higher score in this questionnaire indicated good status and a low score indicated a bad status [20]. To assess life satisfaction, the 
5-item life satisfaction Dieners et al. questionnaire was used that checks whether the person was in a position of cognitive judgment in two comparative states of estimating or not estimating wishes and desires [20].

Each statement had 7 options and was rated from "strongly oppose" (score 1) to "strongly agree" (score 7). The validity and reliability of this scale were measured by Bayani et al. (2007). The validity of this scale was obtained using the Cronbach $\alpha$ coefficient method as 0.83 and with a retest method as 0.69 . The construct validity of the life satisfaction scale was assessed through convergent validity, using the Oxford Happiness Index (OHI) (Argyle, 2001) and the Beck Depression Inventory (BDI) (Beck et al., 1961). The result indicated the validity and reliability of the tool [21].

Self-confidence was assessed based on the 10-item selfconfidence questionnaire of Rosenberg et al. [22]. This questionnaire consists of 10 questions. The answer to each question consists of 4 options (strongly agree, agree, disagree, and strongly disagree) which is given from 1-4 points, so the range of points is from 10-40. A higher score indicates a person's higher self-confidence, with a score of 40 being the highest score. Scores higher than 25 indicate high self-confidence, scores between 15 and 25 indicate moderate self-confidence, and less than 15 indicate low self-confidence [23]. The self-confidence questionnaire is a standard questionnaire whose reliability has been determined based on the opinions of various manufacturers and preliminary studies [24]. Sharifi Nistanak et al. in their study reported the Cronbach $\alpha$ coefficient for this instrument as 0.91 [25]; Mohammadi and Sajjadinejad also reported the Cronbach $\alpha$ coefficients of the Rosenberg self-esteem scale on Shiraz University students at 0.78 [26]. In the study of Akhlaghi et al., this scale had a satisfactory internal validity and its reliability in the test-retest method ranged from 0.88 to 0.77 [27].

Some researchers have reported the internal consistency coefficient of the Rosenberg self-esteem scale as 0.91 [28]. Social support was assessed based on the questionnaire of Zimet et al. (1988). The questionnaire assessed social support from three sources: family (4 questions), friends (4 questions), and important people (4 questions). It had 12 questions scoring based on a 5-point Likert-type scale. In this way, 5 points were given to "strongly agree" and 1 point to be "strongly oppose." The score range was between 12 and 60. Performance capacity was assessed based on the ability to perform activities of daily living (ADL), which is a key indicator of long-term care [29]. If an elderly person is unable to care for himself/herself due to physical or mental health problems, this person needs to be cared for by another person. Long-term care Aims to empower the elderly to maintain the highest possible level of independent functioning.

Functional dependence is the inability to perform one or more of the ADL without help. To assess the ADL status of the elderly were asked in terms of doing housework such as washing, vacuuming, dusting, cooking, home repair by themselves and the need for assistance or supervision in personal care such as showering/bathing, dressing, going to the toilet, as well as helping to trim nails. For each of the above cases, three closed answers "Yes completely," "Yes with help," and "No" were considered to measure the individual's ability that scored as follow: was done by oneself (score 2), needed help (score 1) and complete dependence on the other person (score 0). A high score indicates less need for supervision or assistance in performing ADL and a low score indicates a need for more supervision or assistance in performing ADL. This questionnaire is valid and reliable in Iran [30].

The content validation method was used to determine the validity of data collection tools. Thus, for data collection tools, standard and valid scales available, according to the type of study and the study group, were used. Then the questionnaires were presented to various professors and experts and their suggestions were included in the final questionnaire. In this study, the Cronbach $\alpha$ was calculated to determine the reliability of the questionnaires. The following results were obtained for self-care questionnaires $(0.70)$, willingness to self-care (0.71), life satisfaction (0.85), functional capability (0.71), self-confidence $(0.69)$, and social support (0.85). The questionnaires were filled in several stages, taking into account the resting times of the elderly.

According to Farrell's definition of aging [31], and regarding the comparison of self-care dimensions in different age groups, the elderly were arranged into three groups of young elderly (65-74), middle-aged elderly (75-84), and old elderly (above 85) years. The Chi-square, Pearson correlation and regression analysis were used with a significance coefficient of 0.05 . The data were entered and analyzed in SPSS V. 19. The response rate was $96.25 \%$.

\section{Results}

The Mean \pm SD ages of elderly women and men were $7.47 \pm 67.31$ and $7.47 \pm 70.92$ years, respectively. About $42.5 \%$ of the elderly were male and the rest were female. They lived $42.1 \%$ with a spouse and $26 \%$ alone (Table 1 ).

There was no significant difference between the types of self-care and gender except for the dimensions of work habits $(\mathrm{P}<0.001)$ and medical treatment $(\mathrm{P}<0.001)$ (Table 2$)$. 
Table 1. Mean score of self-care dimensions in the studied elderly

\begin{tabular}{cccc}
\hline Dimensions of Self-Care & Mean \pm SD & Dimensions of Self-Care & Mean \pm SD \\
\hline Awareness and willingness to take care of yourself & $16.17 \pm 2.18$ & Treatment and medication management & $2.18 \pm 8.06$ \\
\hline Physical condition & $24.94 \pm 3.37$ & Work habits & $2.46 \pm 12.33$ \\
\hline Communication with health care staff & $23.17 \pm 3.04$ & Past events & $2.42 \pm 8.59$ \\
Communication with family & $14.35 \pm 1.40$ & confidence & $6.24 \pm 2.87$ \\
\hline Meaningful and stimulating aging & $9.29 \pm 1.47$ & Medical treatment & $4.90 \pm 0.58$ \\
\hline Understanding the future & $11.93 \pm 2.05$ & future perspectives & $2.81 \pm 1.55$ \\
\hline
\end{tabular}

Table 2. Investigating the relationship between self-care dimensions and the gender of the studied elderly

\begin{tabular}{|c|c|c|c|}
\hline \multirow{2}{*}{ Dimensions of Self-care } & \multicolumn{2}{|c|}{ Mean \pm SD } & \multirow{2}{*}{$\mathbf{P}$} \\
\hline & Women & Men & \\
\hline Awareness and willingness to take care of yourself & $16.21 \pm 2.31$ & $16.11 \pm 2.004$ & 0.471 \\
\hline Physical condition & $24.85 \pm 3.48$ & $25.06 \pm 3.23$ & 0.161 \\
\hline Communication with health care staff & $23.19 \pm 3.09$ & $23.15 \pm 2.96$ & 0.553 \\
\hline Communication with the family & $14.28 \pm 1.49$ & $14.33 \pm 1.27$ & 0.103 \\
\hline Meaningful and stimulating aging & $9.17 \pm 1.58$ & $9.43 \pm 1.29$ & 0.352 \\
\hline Understanding the future & $11.87 \pm 2.12$ & $12.02 \pm 1.95$ & 0.385 \\
\hline Treatment and medication management & $7.78 \pm 2.33$ & $8.44 \pm 1.89$ & 0.064 \\
\hline Work habits & $11.38 \pm 2.45$ & $13.59 \pm 1.80$ & $<0.001$ \\
\hline Past events & $8.50 \pm 2.42$ & $8.7 \pm 2.4$ & 0.579 \\
\hline Medical treatment & $4.71 \pm 2.56$ & $8.20 \pm 1.77$ & $<0.001$ \\
\hline Confidence & $4.90 \pm 0.59$ & $4.91 \pm 0.57$ & 0.585 \\
\hline Future perspectives & $2.75 \pm 1.51$ & $2.89 \pm 1.60$ & 0.235 \\
\hline
\end{tabular}

There was a significant relationship between different age groups of the elderly only in terms of knowledge and willingness to take care of themselves, work habits, and past events. However, the two groups were not significantly different in terms of other dimensions (Table 3).

There was a slight and positive statistical relationship between self-care and life satisfaction $(\mathrm{P}=0.01, \mathrm{r}=0.343)$ and a weak and positive relationship between self-care and selfconfidence $(\mathrm{P}=0.01, \mathrm{r}=0.289)$ (Table 4).

\section{Discussion}

In this study, among the dimensions of self-care (awareness and desire to take care of themselves, physical condition, communication with health staff, communication with the family, aging with meaning and stimulation, understanding of the future, treatment and medication management, work habits, past events, and confidence), the highest average was related to "physical condition" and the lowest average was related to "medical treatment and foresight." Therefore, the most important dimension of self-care in the 
Table 3. The relationship between the dimensions of self-care and age groups in the elderly

\begin{tabular}{|c|c|c|c|c|}
\hline \multirow{2}{*}{ Age groups of self-care dimensions } & \multicolumn{3}{|c|}{ Mean \pm SD } & \multirow{2}{*}{$\mathbf{P}$} \\
\hline & $<75 y$ & 75-84 y & $>85 y$ & \\
\hline Awareness and desire to take care of yourself & $2.19 \pm 16.21$ & $2.16 \pm 16.18$ & $2.62 \pm 14.3$ & $<0.001$ \\
\hline Physical condition & $3.45 \pm 24.76$ & $3.10 \pm 25.83$ & $2.79 \pm 25.7$ & 0.8 \\
\hline Communication with health care staff & $3.09 \pm 23.06$ & $2.53 \pm 23.53$ & $1.66 \pm 24.1$ & 0.1 \\
\hline Communication with the family & $1.48 \pm 14.3$ & $1.13 \pm 14.46$ & $0.94 \pm 14.7$ & 0.96 \\
\hline Meaningful and stimulating aging & $1.43 \pm 9.31$ & $1.68 \pm 9.14$ & $1.94 \pm 8.7$ & 0.46 \\
\hline Understanding the future & $2.05 \pm 12.0$ & $2.25 \pm 11.77$ & $1.07 \pm 11.4$ & 0.1 \\
\hline Treatment and medication management & $2.24 \pm 7.88$ & $1.62 \pm 9.02$ & $1.57 \pm 8.6$ & 0.69 \\
\hline Work habits & $2.45 \pm 12.10$ & $1.82 \pm 61 / 13$ & $3.44 \pm 11.1$ & $<0.001$ \\
\hline Past events & $2.51 \pm 8.64$ & $2.11 \pm 8.53$ & $1.81 \pm 8.8$ & $<0.001$ \\
\hline Medical treatment & $2.84 \pm 5.91$ & $2.44 \pm 7.95$ & $2.72 \pm 6.9$ & 0.46 \\
\hline Confidence & $0.55 \pm 4.91$ & $0.89 \pm 4.78$ & $0.1 \pm 5$ & 0.99 \\
\hline Future perspectives & $1.53 \pm 2.76$ & $1.65 \pm 3.80$ & $1.64 \pm 2.40$ & 0.73 \\
\hline
\end{tabular}

elderly is their physical condition, because self-care is a practice in which each person uses their knowledge, skills, and abilities as a resource to "independently" take care of their health. In the meantime, the physical condition can be the key dimension in elderly self-care. Medical treatment in the elderly is often inappropriate and wrong, which can be attributed to the complexity and frequency of prescription treatments due to the presence of various chronic diseases. Also, in this study, the known effective factors on self-care of the elderly in Tehran City were "tendency to self-care," "life satisfaction," "self-confidence," "functional capability," and "social support."

According to a 2003 Backman study [32] and studies by Rabiner et al. [33] and Blair, self-care in the elderly is associated with functional capacity, life satisfaction, and self-confidence. Therefore, in this study, these factors were addressed and it was shown that by increasing the types of self-care and the tendency to it, the level of life satisfaction and self-confidence increases [34-36].

Other studies have shown that the functional capacity of older people is dependent on self-care in them [10] and [31] in this study, a direct and significant relationship was found between social support and the tendency to self-care behaviors. Backman and Hentinen also showed that social support promotes self-care activities in the elderly [10]. Regarding the role of social support, Isola et al. showed that relatives play a very important role in the self-care of the elderly [37].

The social support provided by the spouse and how it affects self-care behaviors has shown that the quality of marriage and marital intimacy leads to better self-care knowledge [38]. A study by Gallagher et al. (2011) found that higher social support in patients with heart failure compared with those with low or moderate social support increased consultation with health professionals about weight loss $(\mathrm{P}=0.01)$, fluid restriction $(\mathrm{P}=0.02)$, and drug use $(\mathrm{P}=0.017)$ [39].

It seems that social support increases a person's motivation to take care of themselves. Based on the Findings of this study, there was a direct and significant relationship between self-confidence and self-care behaviors. Self-confidence is the result of self-esteem as well as the self-esteem of others. Evidence suggests that receiving respect from others increases self-care behaviors, promotes health, and prevents disease [40] and low self-esteem is a deterrent to self-care behaviors [41]. Since self-care is one way to earn the respect of others, older people with higher self-esteem 
Table 4. The relationship between Variabels in the elderly

\begin{tabular}{|c|c|c|c|c|c|c|}
\hline Variabels & Types of self-care & Self-care Orientation & Life Satisfaction & Self Steem & Functional Ability & Social Support \\
\hline $\begin{array}{l}\text { Types of } \\
\text { self-care }\end{array}$ & 1 & & & & & \\
\hline $\begin{array}{l}\text { Self-care Orien- } \\
\text { tation }\end{array}$ & 0.266 & 1 & & & & \\
\hline Life Satisfaction & 0.343 & 0.015 & 1 & & & \\
\hline Self Steem & 0.289 & 0.186 & 0.424 & 1 & & \\
\hline $\begin{array}{l}\text { Functional } \\
\text { Ability }\end{array}$ & -0.095 & -0.033 & -0.093 & 0.055 & 1 & \\
\hline Social Support & -0.075 & 0.073 & 0.132 & 0.047 & 0.183 & 1 \\
\hline
\end{tabular}

were more likely to engage in self-care behaviors. Gaining the respect of others is one way to gain self-confidence.

The results of this study showed no significant difference between the dimensions of self-care except occupational habits $(\mathrm{P}<0.001)$ and medical treatment $(\mathrm{P}<0.001)$ between men and women. Lantz study, on the other hand, showed that women are more inclined to self-care than men [42]. In this study, there was a correlation between gender and the self-care dimension of work habits. There was also a correlation between gender and the self-care dimension of medical treatment. The average man was higher than women. Perhaps this finding can be interpreted because jobs are more important to men and they are more accustomed to their jobs than women. In order not to lose their job, men show more job-appropriate self-care behaviors than women. Also, men do not believe in traditional medicine and self-medication more and prefer medical treatment, but women are more in favor of traditional medicine and selfmedication.

Statistical tests showed a significant difference between different age groups of the elderly in terms of knowledge and willingness to take care of themselves, work habits, past events. In this study, "awareness and willingness to take care of themselves" and "work habits" among the elderly age groups, young elderly, and middle-aged elderly were more than the old elderly. A review of the literature in this field shows an inverse and significant relationship between "awareness and desire for self-care" with age [42, 43] so that with increasing age, "awareness and desire for self-care in the elderly" decreases, which can be partially the ability to reduce the ability to self-care in them and related cognitive problems and issues. Accordingly, a positive and significant relationship has been shown between elderly awareness, self-care, and daily habits [43]. The relationship between awareness and self-care has also been shown by other studies [44, 45]. Studies and documents in this field show a significant relationship between increasing age and decreasing functional capacity $[46,47]$.

The average self-care dimension of "past events" was higher among the old elderly group than other age groups. Obviously, with increasing age and the decline in quality of life and the significant positive relationship that exists between all aspects of self-care and quality of life [48, 49], self-care of "past events" help the elderly to find their identity, alleviate discomfort, and disability.

This study was conducted in nursing homes in Tehran City and so the generalizability of its results to other elderly people is limited. Therefore, we recommended further studies at the national level to determine self-care challenges and factors affecting it [50].

\section{Conclusion}

Factors such as life satisfaction, functional capacity, social support, and self-confidence are associated with self-care in the elderly. It is suggested that health policymakers design programs support the elderly in various forms, such as designing programs for easy access of the elderly to transportation, facilities, tax exemptions, and so on.

It is suggested that national policies be developed with the aim of independence of the elderly and with an elderly-oriented approach. All measures to help the elderly should be exempt from taxes. The government should provide easy access to the community, proper housing, proper transportation services, as well as full-time home care services for 
the elderly. The government should take measures in the fields of health, sports, and medicine for the elderly.

\section{Ethical Considerations}

Compliance with ethical guidelines

This study was approved by the Ethics Committee of Alborz University of Medical Sciences (Abzum. Rec.1396.207).

Funding

The study support financially by Alborz University of Medical Sciences.

Authors' contributions

All authors contributed equally in preparing all parts of the research.

Conflicts of interest

The authors declared no conflict of interest.

Acknowledgements

We would like to thank reseach committee of Alborz and Tehran University of Medical Sciences. 


\title{
بلكاركيرى مدل Backman در تعيين ابعاد خُودراقبتى و عوامل مؤثر بر آن در سالمندان شهر

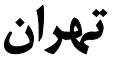

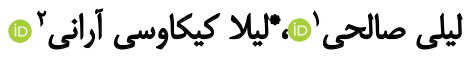

ا. كروه آموزش بهداشت وارتقاء سلامت، مركز تحقيقات بهداشت، ايمنى و محيط، دانشكده بهداشت، دانشعاه علوم يزٔشكى البرز، كرج ، ايران.

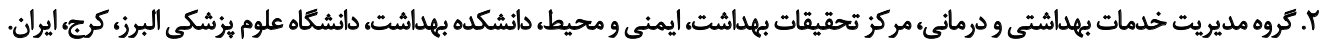

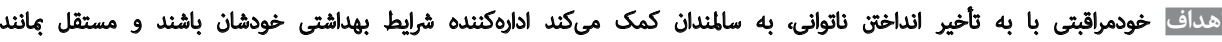

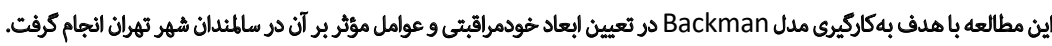

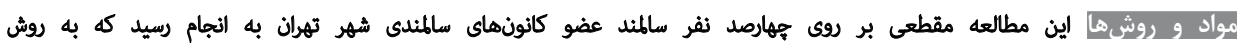

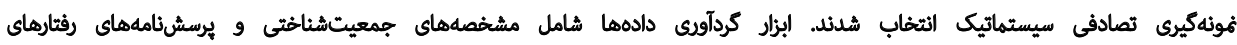

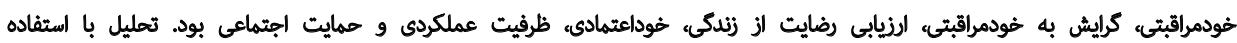

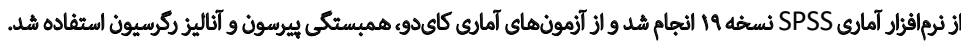

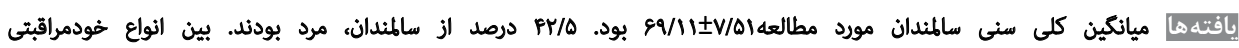

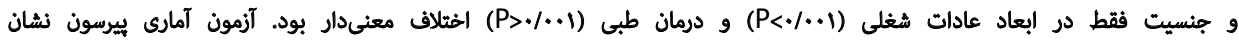

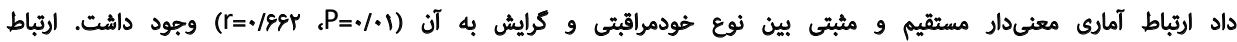

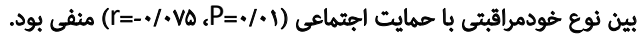

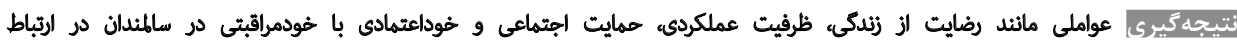

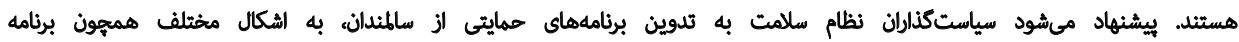

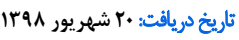

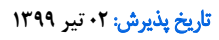

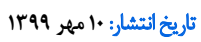

آنان براى مراقبت از خود اثر مىكذارد [9]. نتايج تهقيقات نشان

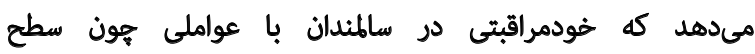

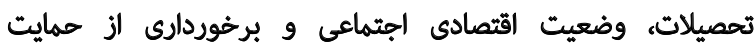

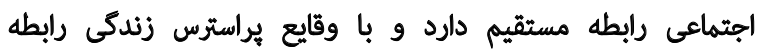

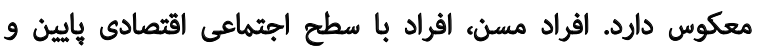

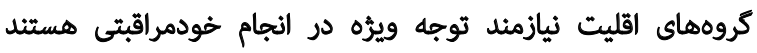

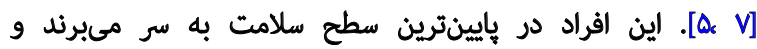

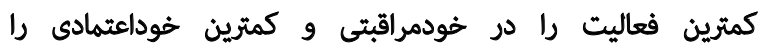

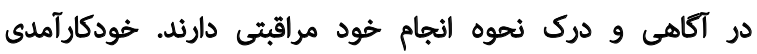

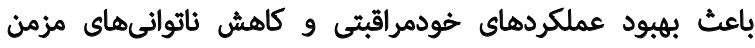

مىشود [1]].

در مطالعات مختلف مشخص شده است، خودمراقبتى سالمندان

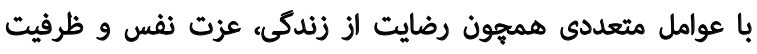

dateo

خودمراقبتى دربركيرنده فعاليتهايى است كه انسانها به مانه

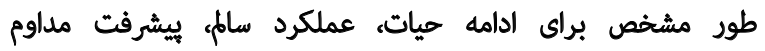

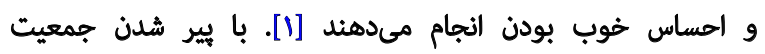

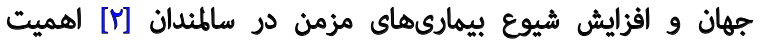

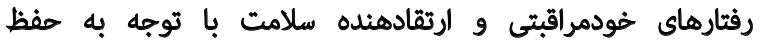

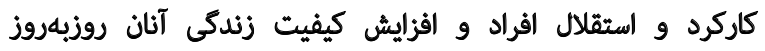

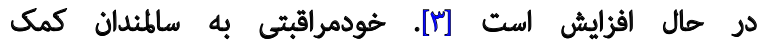

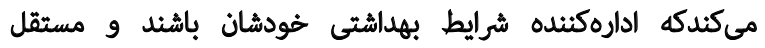

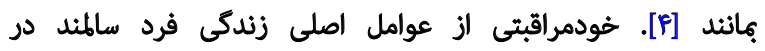

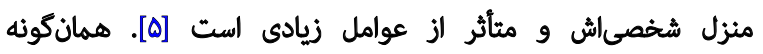

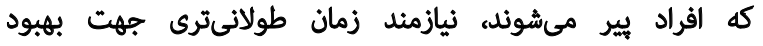

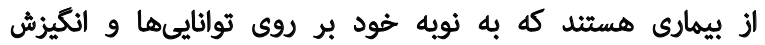

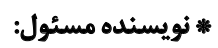

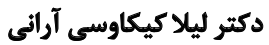

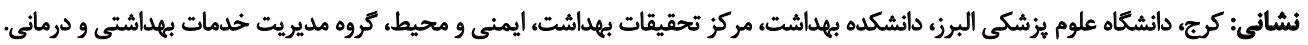

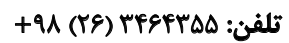
بست الكترونيكي: leila_keikavoosi@yahoo.com 


\section{مواد و روشها}

اين مطالعه مقطعى (توصيفى تحليلى) بر روى جهارصد نفر

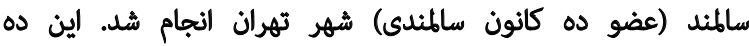

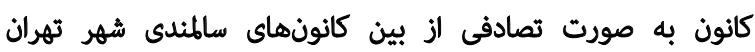

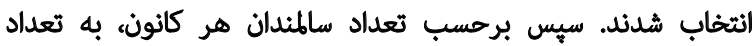

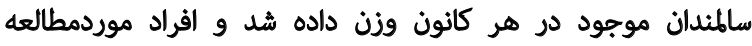

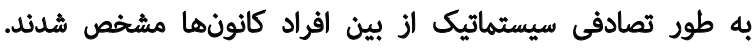

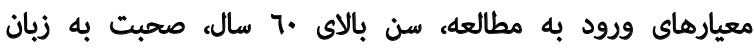

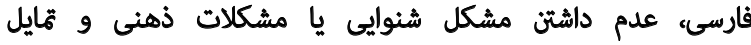

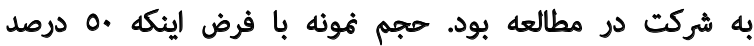

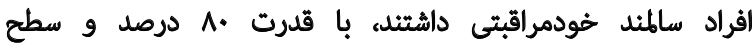

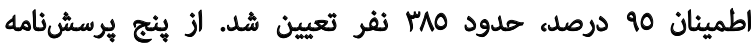

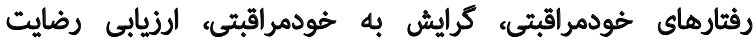

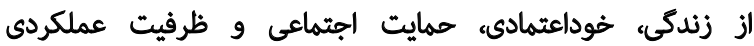

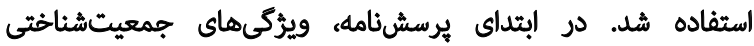

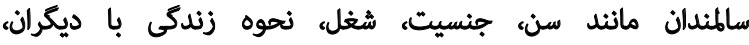
وضعيت تأهل در نظر كرفته شد.

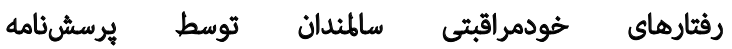

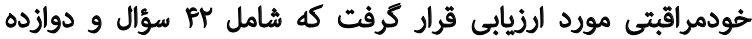

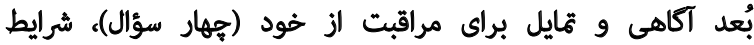

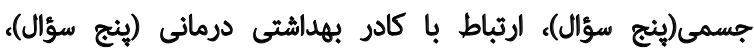

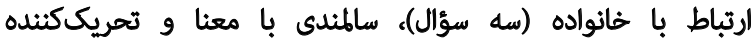

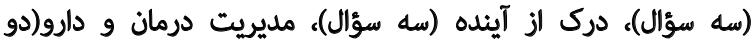

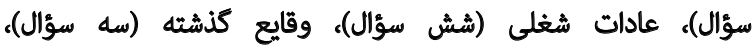

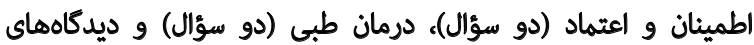

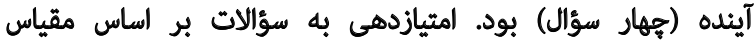

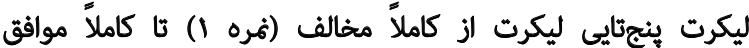

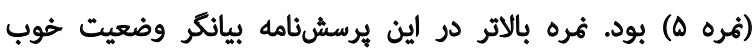

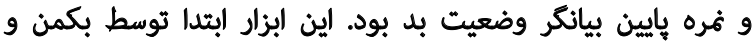

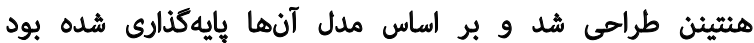

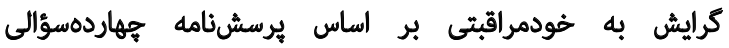

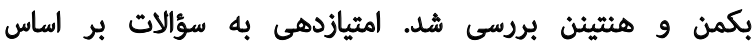

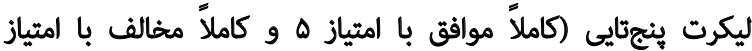

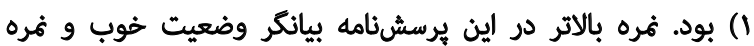

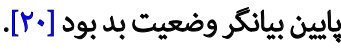

براى ارزيابى رضايت از زندكى از برسشنامه ينجسؤالى رضايت

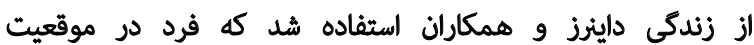

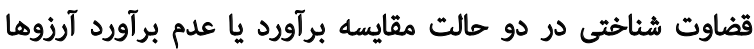

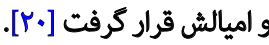

هر كزاره دالراى هفت كزينه بود و از كاملاً مخالف (نمره (1)

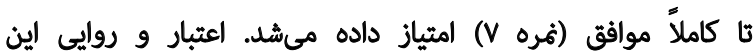

عملكردى، سطح تحصيلات، واكثش خانواده و حمايت خانواده

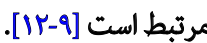

تريسى و همكاران در هئوهش ديكرى با عنوان "كلينيك بيامد:

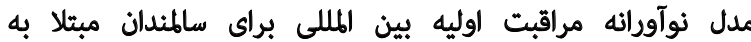

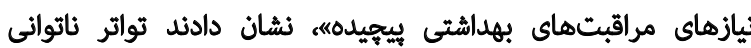
و اثر آن بر شرايط زندكى، دو عامل مهم تعيينكثنده كيفيت دئي

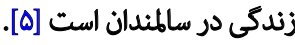

المـروزه بـا اقزايش ميانكيـن اميد به زندكى، تغييـر معنىدارى

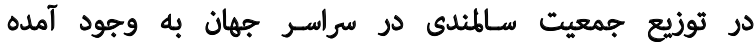

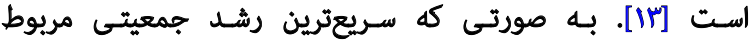

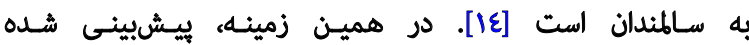

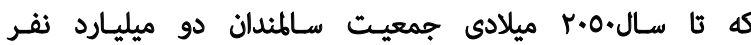

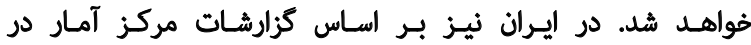

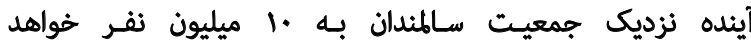
رسيد [10].

سالمندى جمعيت و افزايش سهم افراد سالخورده در جمعيت.

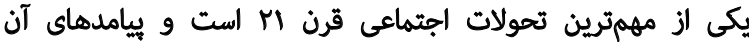

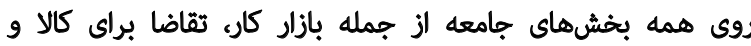

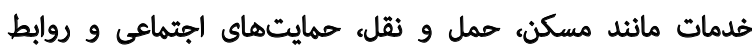

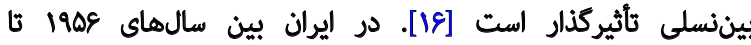

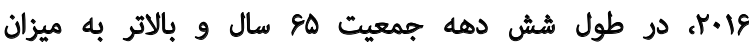

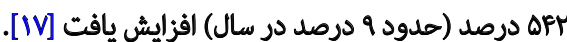

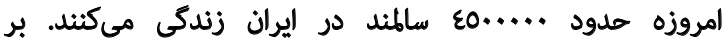

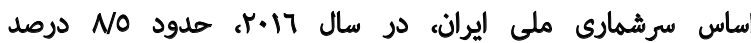

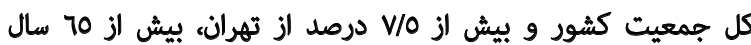

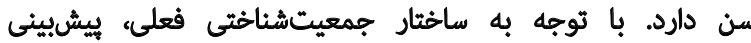

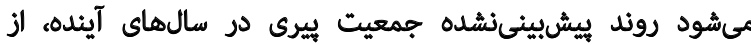
Y.0. Pال مال V/TV

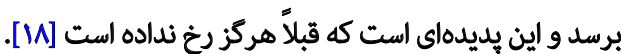
سالمندى به معنى ناثوانى نيست و ارائه برنامههاي خودمديريتى

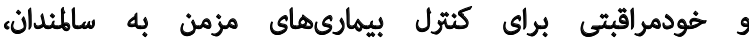

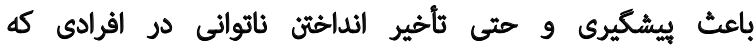
بيمارىهاى مزمنى هون آرترتيت، بيمارىهاى قلبى ياتير يا فشارخون دارنله ميشود.

با توجه الثرات انكار نايذير و كليدى خودمراقبتى بر سالمندى

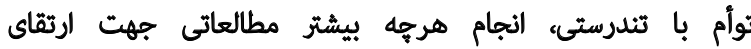

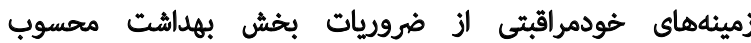

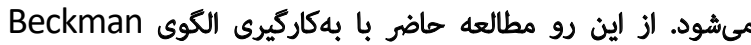

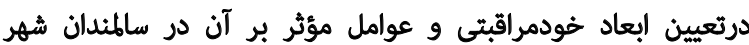

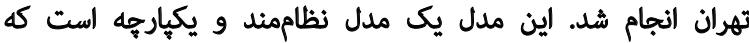
به شفافسازي دانش خودمراقبتى سالمندان مئيردازد. 
وابستكى عملكردى به عنوان ناتوانى در النجام يك يا هند

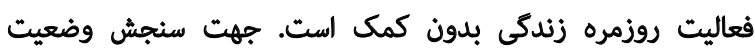

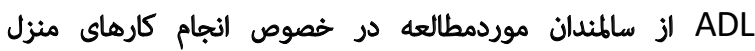

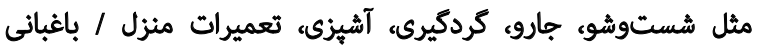

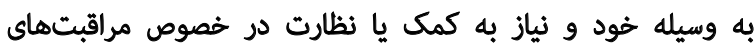

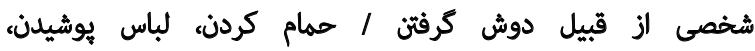

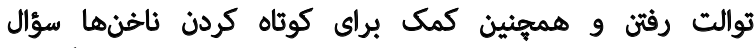

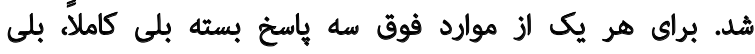

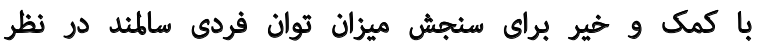

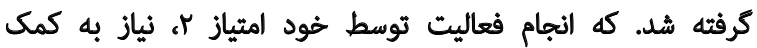

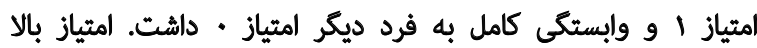

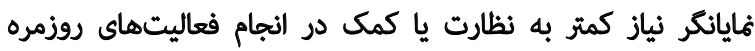

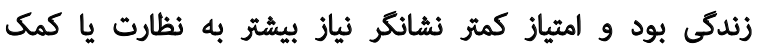

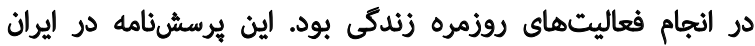

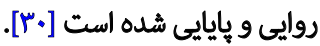

جهت تعيين اعثبار البزاركردآورى دادهها از روش اعتبار محتوا

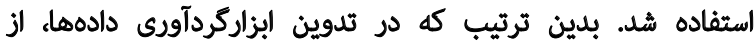

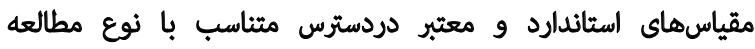

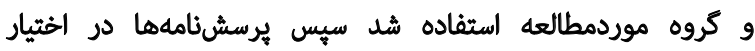

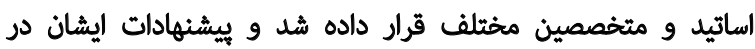

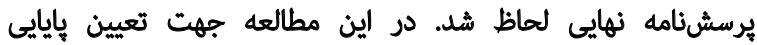

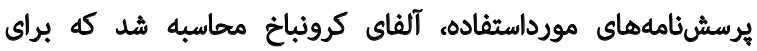

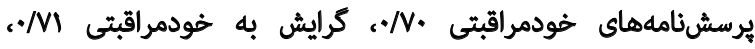

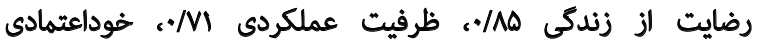

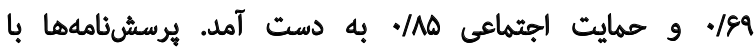

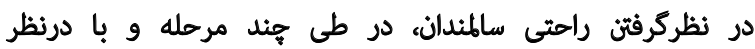
كرفتن زمانهاي استراحت ئر شدند.

در خصوص مقايسه ابعاد خودمراقبتى در كروههاى سنى مثفاوت بر اساس تعريف فارل از انواع ييرى [اسب]، افراد سالمند

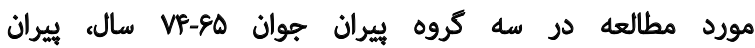
ميانسال AF-VQ

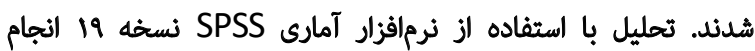

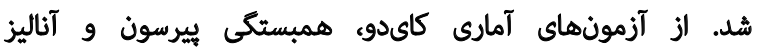

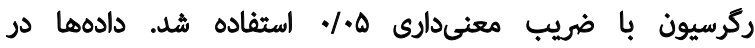
نرمافزار آمارى

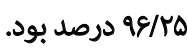

Ladiọl

ميانكين سنى زنان سالمند RV/MIIVV و ميانكين سنى

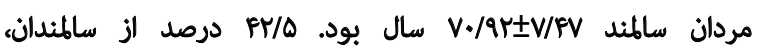

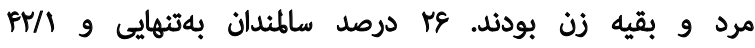

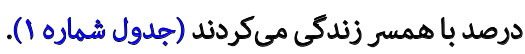
بين انواع خودمراقبتى و جنسيت به جز در ابعاد عادات شغلى
مقياس توسط بيانى و همكاران سنجيده شد. اعتبار اين مقياس با

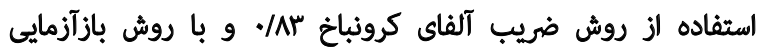

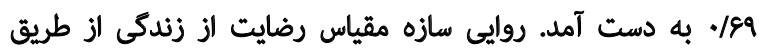

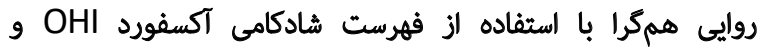

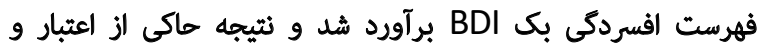

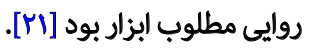

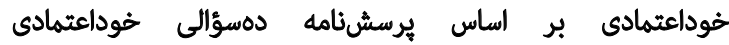

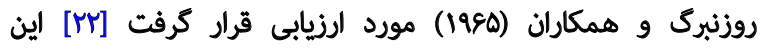

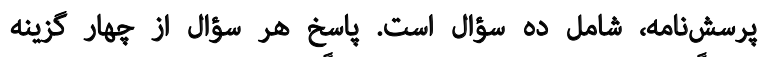

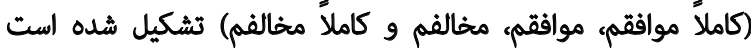

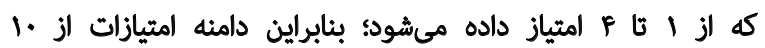

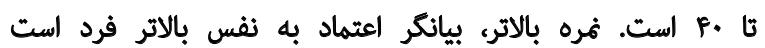

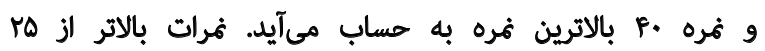

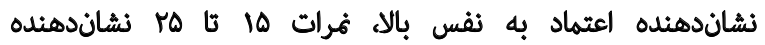

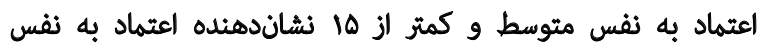

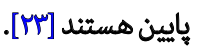

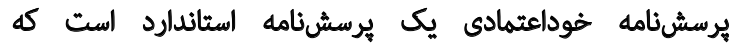

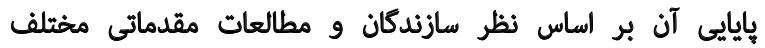

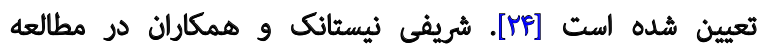

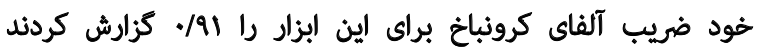

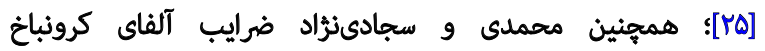
مقياس خوداعتمادى روزنيرى را روى دانشجوين مديان دانشعاه شيراز

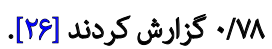

در مطالعه اخلاقى و همكاران نيز اين مقياس از روايى درونى

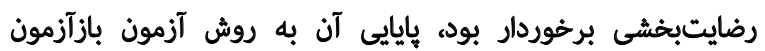

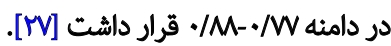

برخى محققين ضريب همسانى درونى مقياس خوداعتمادى

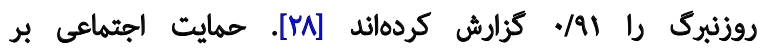

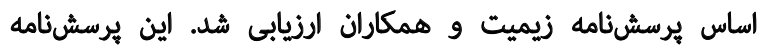

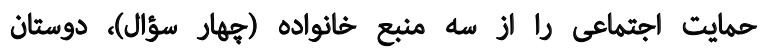

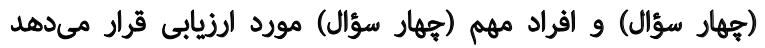

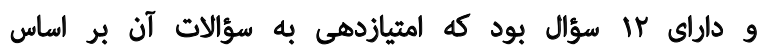

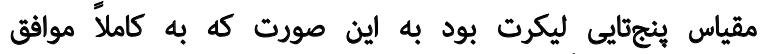

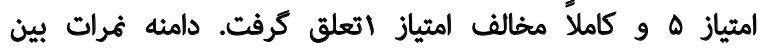
ir

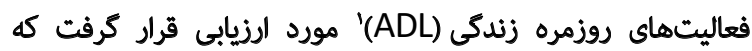

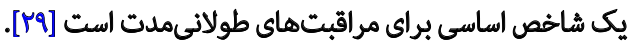

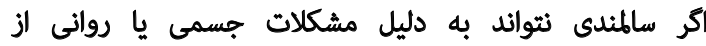

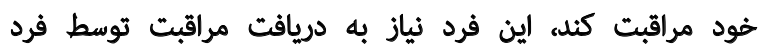

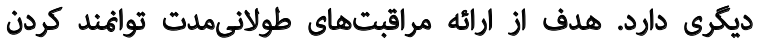

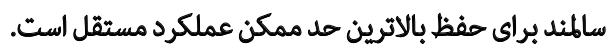
1. Activity of daily living 


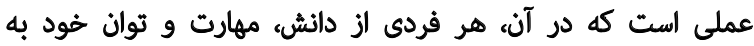

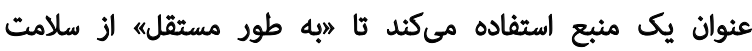

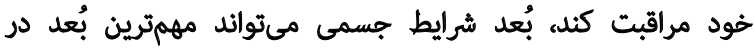

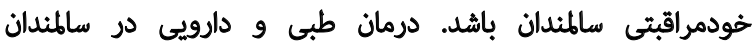

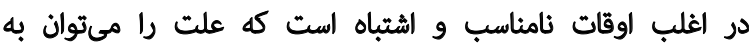

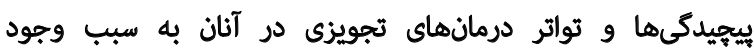
بيمارىهاى مزمن متعدد مربوط دانست.

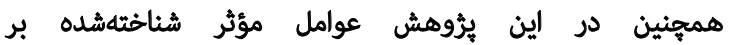

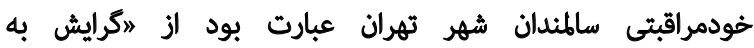

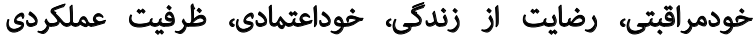
و حمايت اجتماعى"ه.

بر اساس مطالعه بكمن در سال ب...T [بس] و مطالعات

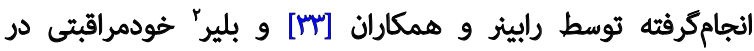

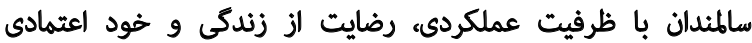

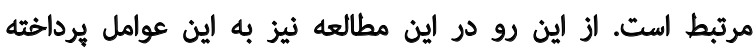

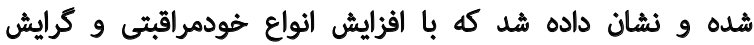
به آن بر ميزان رضايت از زندكى و خوداعثهادى افزوده مى آشود

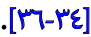

ساير مطالعات نيز نشان دادهاند كه ظرفيت عملكردى افراد

Blair .2
(P< )

(جدول شماره (r).

بين كروههاى سنى مختلف از سالمندان فقط از نظر آكاهى

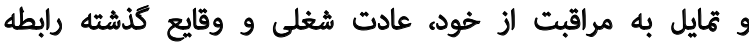

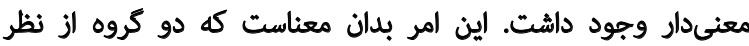

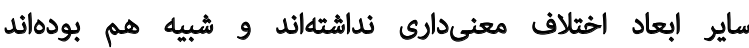
(جدول شماره (r).

بين خودمراقتي با رضايت از زندكى ارتباط آمارى خفيف

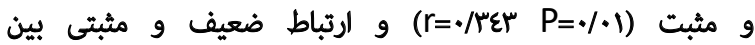

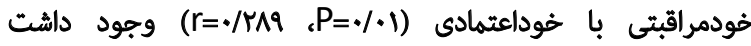

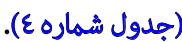

بحث

در اين يُروهش ابعاد خودمراقبتى شامل پآكاهى و ثمايل

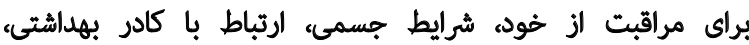

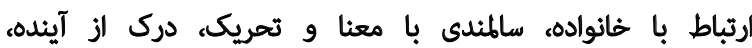

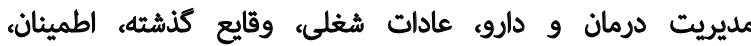

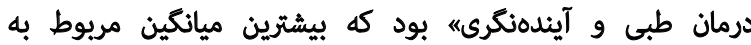

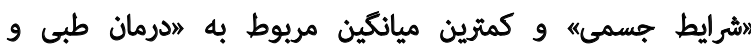

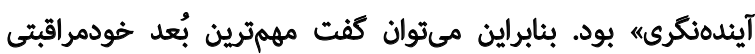

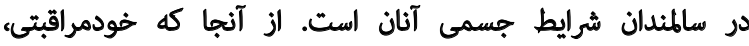

جدول ا. ميائكين امتياز ابعاد خودمراقبتي در سالمندان مورد مطالعه

\begin{tabular}{|c|c|}
\hline ميانكين ثانحراف معيار & ابعاد خودمراقبتى \\
\hline $1 \& / / V \pm T / M$ & آكاهي و تمايل براى مراقبت از خود \\
\hline$m / q u \pm m / m$ & شرايط جسمى \\
\hline$m / / v \pm m / . \varphi$ & ارتباط با كادر بهداشتى درمانى \\
\hline$\left|f / r^{\mu} \Delta \pm\right| / F$ & ارتباط با خانواده \\
\hline$q / r q \pm 1 / F$ & سالمندى با معنا و تحريك كننده \\
\hline$W / Q T \pm r / \cdot \Delta$ & درى از آيثده \\
\hline$N \cdot F \pm r / M$ & مديريت درمان و مارو \\
\hline IY/MYET/Re & عادات ششلى \\
\hline$N \Delta Q \pm T / F T$ & وقايع كذشتشه \\
\hline G/RFIT/AV & الطميثان \\
\hline$F / Q . \pm . / Q A$ & درمان طبي \\
\hline$r / A) \pm V / \Delta \Delta$ & آيندهنكرى \\
\hline
\end{tabular}


جدول r. بررسى ارتباط بين ابعاد خودمراقبتى با جنسيت سالمئدان موردمطالعه

\begin{tabular}{|c|c|c|c|}
\hline \multirow{2}{*}{$\mathbf{P}$} & \multicolumn{2}{|c|}{ جنسيت } & \multirow{2}{*}{ ابعاد خودمراقبتى } \\
\hline & مردان & زنان & \\
\hline.$/ 2 n$ & $\mid \varphi / 11 \pm r / \ldots r$ & $|E / r| \pm r / r \mid$ & آكاهى و تمايل براى مراقبت از خود \\
\hline. $\mid 191$ & $r \Delta / \cdot g \pm T / R r$ & $r F / \Lambda \Delta \pm Y / F A$ & شرايط جسمى \\
\hline$\cdot / \Delta \Delta r$ & $M T / 1 \Delta \pm T / Q$ & $\pi / 19 \pm m / .9$ & ارتباط با كادر بهائشتى درماثي \\
\hline.$/ . r$ & $I E / M T \pm I / T V$ & 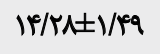 & ارتباط با خانواده \\
\hline - $/ r \Delta r$ & $q / T+1 / T q$ & $q / / V \pm / / A M$ & سالمندى با هعنا و تحريك كثنده \\
\hline -/ras & $\mid r / \cdot r \pm 1 / 9 \Delta$ & IV/AVET/Mr & درى از آينده \\
\hline .1 .98 & $N / P I / / 19$ & $V / V A \pm T / M T$ & مديريت درمان و دارو \\
\hline$<+1 *+1$ & $\mid r / \Delta q \pm 1 / \Lambda$ & 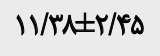 & عادات شُغلى \\
\hline - /DV & $N V \pm Y / F$ & $N \Delta \cdot \pm T / A T$ & وقايع كذشته \\
\hline$<+1 \cdot+1$ & $N r \cdot \pm \mathbb{M} /$ & $F / M I+r / \Delta F$ & درمان طبي \\
\hline$. / \Delta / \Delta$ & $f / q) \pm \cdot / \Delta V$ & $F / q \cdot \pm \cdot / \Delta q$ & اطمينان \\
\hline.$/ \pi T \Delta$ & ร/Aq $\pm 1 / 8$. & $r / N \Delta \pm(\mid \Delta)$ & آيندهنكرى \\
\hline
\end{tabular}

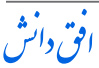

جدول ج. بررسى ارتباط بين ابعاد خودمراقبتى و كروههاى سنى در سالمندان موردبررسى

\begin{tabular}{|c|c|c|c|c|}
\hline \multirow{2}{*}{$\mathbf{P}$} & \multicolumn{3}{|c|}{ انحراف معيار دميانكين } & \multirow{2}{*}{ اد خودمراقبتى } \\
\hline & $10<$ & 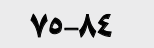 & Vos & \\
\hline$<* 1 . .1$ & $\mid F / M \pm r / F r$ & $18 / 1 \lambda \pm T / 18$ & $|\& / r| \pm r / 19$ & أكاهي و تمايل براي مراقبت از خُود \\
\hline$+/ 1$ & $r \Delta / V \pm r / V q$ & $r \Delta / \Lambda \mu \pm \Psi / \Lambda$. & $M F / V \varepsilon \pm \Psi / F \Delta$ & شرايط جسمى \\
\hline .11 & $r F / \pm 1 / \& \&$ & $M T / \Delta H \pm Y / \Delta r$ & $M T / \cdot g \pm \Psi / \cdot 9$ & ارتباط با كادر بهها:شتى درماتى \\
\hline .19 & $\mid f / V \pm . / 9 f$ & $\mid f / F E \pm 1 / 1 r$ & $|\varphi / \% \pm| / P A$ & ارتباط با خانواده \\
\hline.$/ 18$ & $\mathcal{N V} \pm / / 9 F$ & $V / / f \pm V / 8 \lambda$ & $q / r \mid \pm 1 / r r$ & سالمندى با معنا و تحريك كننده \\
\hline.$/ 1$ & $11 / F \pm V / * V$ & $11 / W \pm r / T \Delta$ & $\mid r / \cdot \pm r / \cdot \Delta$ & درى از أينده \\
\hline .189 & $N F \pm 1 / \Delta V$ & $q \cdot r \pm$ Ver & $V / M \pm Y / M F$ & مديريت درمان و دارو \\
\hline$<+*+1$ & $1 W / 1 \pm \pi / \mu p$ & $|r / 8| \pm 1 / A r$ & $\mid r / 1 \cdot \pm r / P Q$ & عادات شغلى \\
\hline$<+/+\infty$ & $N A \pm \mid / A 1$ & $N \Delta M^{M} \pm Y M$ & $N A+ \pm T / Q 1$ & وقايع كَذشته \\
\hline.$/ 48$ & $g / q \pm r / r r$ & $V / Q \Delta \pm r / H Y$ & $\Delta / 9 I \pm T / \lambda F$ & 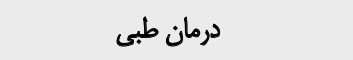 \\
\hline .199 & $\Delta \pm . /$ & $F / V A \pm \cdot / 19$ & $f / 91 \pm \cdot / \Delta \Delta$ & | اطمينان \\
\hline$\cdot / N^{n}$ & $r / f \cdot \pm I / R t$ & $\Gamma / \cdot \Lambda \pm V / 8 \Delta$ & $r / V q \pm V / \Delta r$ & آيندهنكرى \\
\hline
\end{tabular}


جدول f.ارتباط بين خودمراقبتى، كرايش به خودمراقبتى، رضايت از زندكى، خوداعتمادى وظرفيت علمكردى و حمايت اجتماعى در سالمثدان موردبررسى

\begin{tabular}{|c|c|c|c|c|c|c|}
\hline اجتمايتى & غملكردى & خوداعتمادى & رضايت از زندكى & خودرايش به بهى & نوع خودمراقبتى & متغيرها \\
\hline & & & & & 1 & نوع خودمراقبتى \\
\hline & & & & 1 & . Trgen & كرايش به خودمراقبتى \\
\hline & & & 1 & .1 .10 & $. / m a r+\infty$ & رضايت ازز زندكى \\
\hline & & 1 & ./ATpeos & . MWE** & . /KA9** & خوداعثمادى \\
\hline & 1 &.$- / . \Delta \Delta$ & -.1 .94 & $-.1 .+\pi$ &.- .1 .90 & ظرفيت عملكردى \\
\hline 1 & . MAres & $\%+\mathrm{pr}$ & טיזות" &.$/ r^{2}$ & $-\cdot / \cdot \vee \Delta$ & حمايت اجتماعى \\
\hline
\end{tabular}

يافتههاى اين مطالعه نشان داد اختلاف معنىدارى بين ابعاد

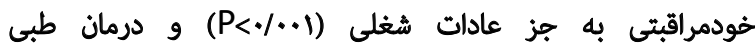

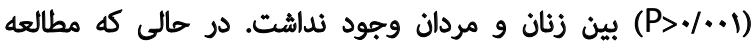

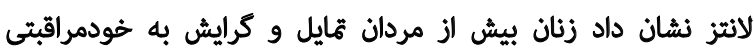

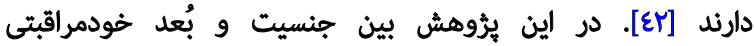

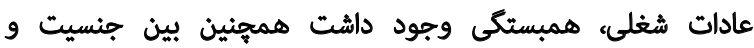

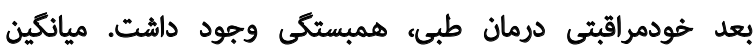

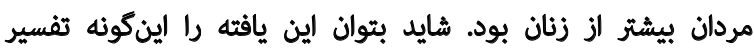

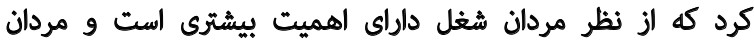

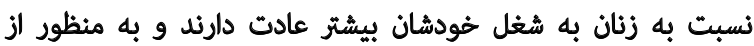

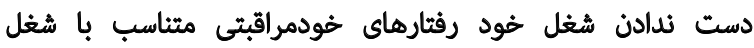

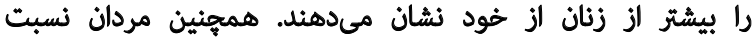

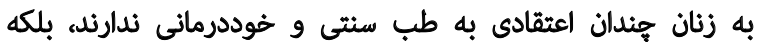

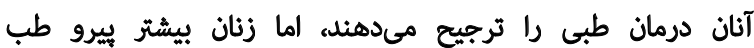
سنتى و خوددرمانى هستيتد. آزمونهاى آمارى نشان داد تفاوت معنىدارى بين كروههاى

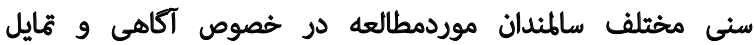
برايى مراقبت از خوده عادات شغلى و وقايع كذشته وجود دارئل دارد. درد

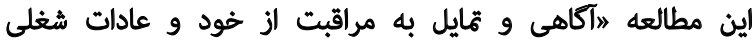

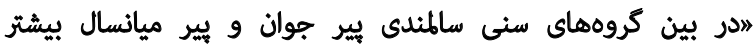

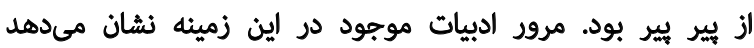

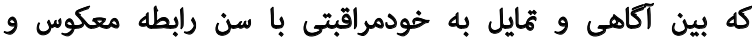

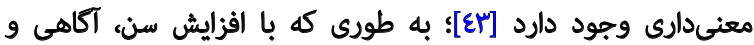

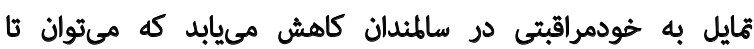

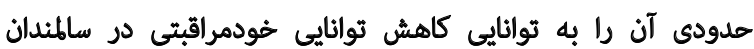

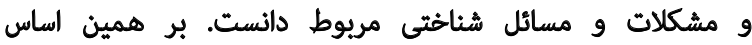

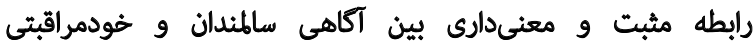

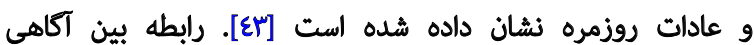
و خودمراقبثى توسط ساير مطالعات نيز نشان داده شده است
سالمند با خودمراقبتى در آنان وابسته است [.ا، آس]. در اين مطالعه رابطه مستقيم و معنادارى بين حمايت اجتثماعى و كرايش

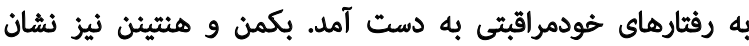

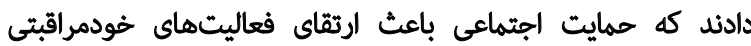

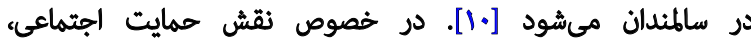

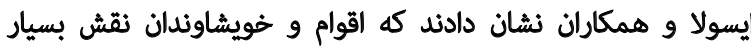

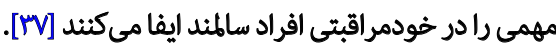
حمايت اجتماعى مبذولشده از سوى همسر و نحوه ثأثير آن

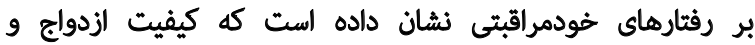

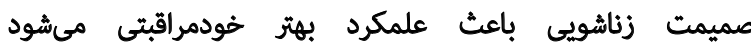

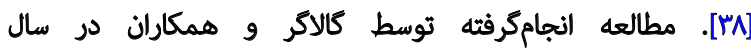

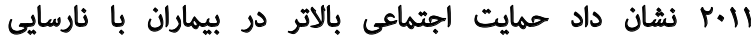

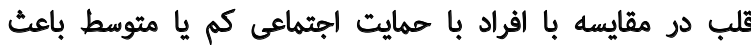

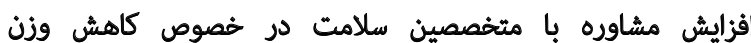
الز

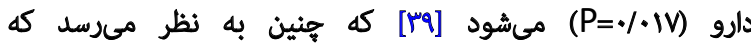

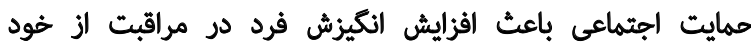

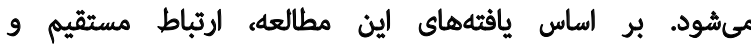

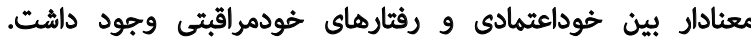

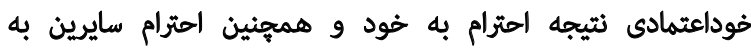

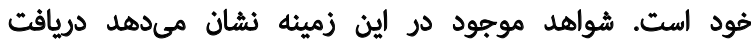

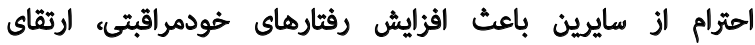

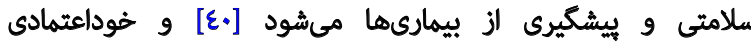

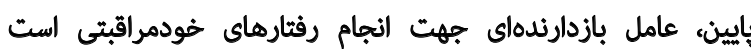

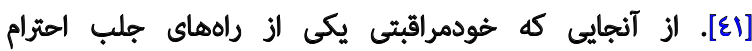

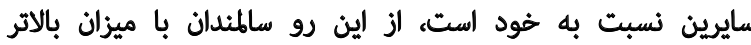

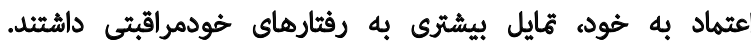

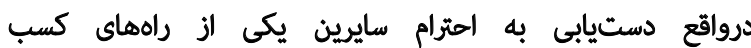
خوداعتمادى است. 
منبع مالى اين طرح يروهشى توسط دانشكاه علوميزشكى البزز

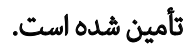

\section{مشاركت نويسندكّان}

ثمامى نويسندكان به يك الدازه در نكارش اثر مشاركت مانئild

$$
\text { تعارض مناقع }
$$

بنابر اظهار نويسندكان اين مقاله تعارض منافع ندارد.

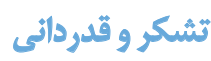

بدين وسيله از مديريت كانونهاى سالمندى شهر تهران و كليه

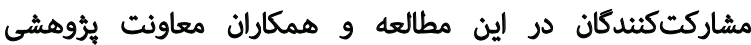
دانشكاههاى البرز و تهران تشكر و سياس كزارى مي وشود.
. [ $[0, \varepsilon \varepsilon]$

مطالعات و مستندات موجود در اين زمينه كوياي رابطه معنى اراى بين افزايش سن و كاهش ظرفيت عملكردى هستند

[ [ EV E ET]

ميانكين بُعد خودمراقبتى وقايع كذشته در بين كروه سنى يير

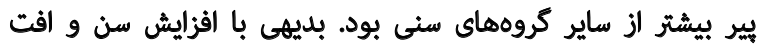

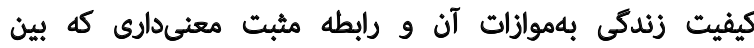

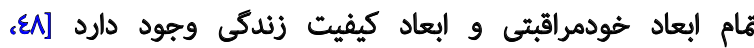

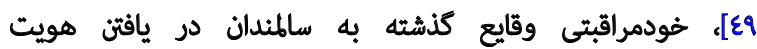

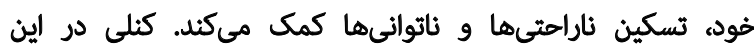

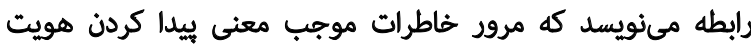

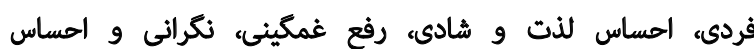

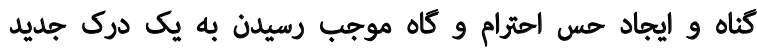

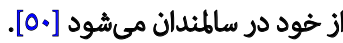

$$
\text { تتيجنميرى }
$$

عواملى مانند رضايت از زندكى، ظرفيت عملكردى، حمايت

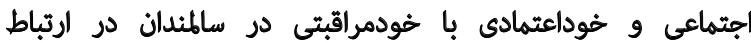

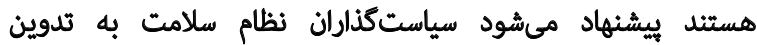

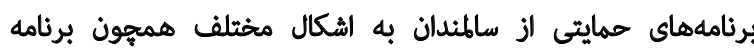

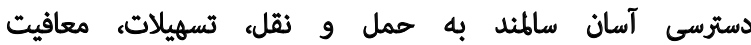
مالياتى و غيره اهتمام ورزند.

ويشنهاد مىشود سياستهاى ملى با هدف استقلال سالمندان

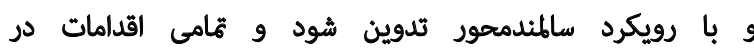

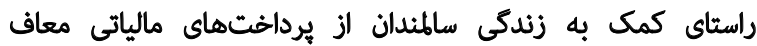

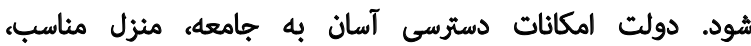

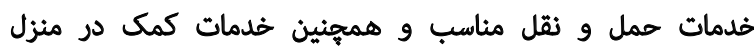

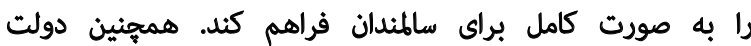

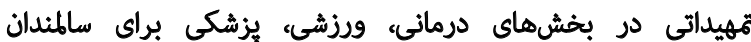

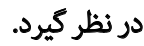

اين مطالعه در كانوذهاى سالمندى شهر تهران انجام كرفت و با محدوديتهايى در تعميميذيرى نتايج آن به دائه ساير سالمندان مواجه است. الز اين رو مطالعات كسترده در سطح ملى برائ دائ تعيين

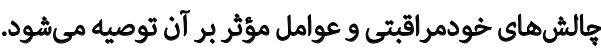

مالاحظات اخلاقى

\section{بيروى أو الصول اخلاق يُؤهش} اين مطالعه با كد اخلاق Abzum.Rec.1396.207 به تصويب المردي دانشكاه علومزشكى البرز رسيده است. 


\section{References}

[1] Dickstein K, Cohen-Solal A, Filippatos G, McMurray JJ, Ponikowski $\mathrm{P}$, Poole-Wilson PA, et al. ESC guidelines for the diagnosis and treatment of acute and chronic heart failure 2008: The task force for the diagnosis and treatment of acute and chronic heart failure 2008 of the European Society of Cardiology. Developed in collaboration with the Heart Failure Association of the ESC (HFA) and endorsed by the European Society of Intensive Care Medicine (ESICM). European Journal of Heart Failure. 2008; 10(10):933-89. [DOI:10.1016/j. ejheart.2008.08.005] [PMID]

[2] van Oostrom SH, Gijsen R, Stirbu I, Korevaar JC, Schellevis FG, Picavet HSJ, et al. Time trends in prevalence of chronic diseases and multimorbidity not only due to aging: Data from general practices and health surveys. PLoS One. 2016; 11(8):e0160264. [DOI:10.1371/journal.pone.0160264] [PMID] [PMCID]

[3] Lin W, Lee YW. Nutrition Knowledge, attitudes, and dietary restriction behavior of the Taiwanese elderly. Asia Pacific Journal of Clinical Nutrition. 2005; 14(3):221-9. [PMID]

[4] Lee TW, Ko IS, Lee KJ. Health promotion behaviors and quality of life among community dwelling elderly in Korea. International Journal of Nursing Studies. 2005; 49(2):129-37. [DOI:10.1016/j.jinurstu.2005.06.009] [PMID]

[5] Tracy CS, Bell SH, Nickell LA, Charles J, Upshur REG. The IMPACT clinic: Innovative model of interprofessional primary care for elderly patients with complex health care needs. Canadian Family Physician. 2013; 59(3):e148-55. [PMID] [PMCID]

[6] Toye C, White K, Rooksby K. Fatigue in frail elderly people. International Journal of Palliative Nursing. 2006; 12(5):202-8 [DOI:10.12968/ijpn.2006.12.5.21172] [PMID]

[7] Awang H, Mansor N, Nai Peng T, Nik Osman NA. Understanding ageing: Fear of chronic diseases later in life. Journal of International Medical Research. 2018; 46(1):175-84. [DOI:10.1177/0300060517710857] [PMID] [PMCID]

[8] Macabasco-O'Connell A, Crawford MH, Stotts N, Stewart A, Froelicher ES. Self-care behaviors in indigent patients with heart failure. Journal of Cardiovascular Nursing. 2008; 23(3):223-30. [DOI:10.1097/01.JCN.0000317427.21716.5f] [PMID]

[9] Räsänen PM, Kanste O, Elo S, Kyngäs H. Factors associated with the self-care of home-dwelling older people. Journal of Nursing Education and Practice. 2014; 4(8):90-6. [DOI:10.5430/jnep.v4n8p90]

[10] Zeleznik D. Self-care of the home-dwelling elderly people living in Slovenia [PhD dissertation]. Oulu: University of Oulu. http://jultika. oulu.fi/files/isbn9789514286377.pdf

[11] Vasli P, Eshghbaz F. [Survey condition regarding self- caring of children suffering from diabetes type 1 and it's relation with family reaction (Persian)]. Journal of Mazandaran University of Medical Sciences. 2009; 19(69):38-44. http://jmums.mazums.ac.ir/article1-536-fa.html

[12] Morovati Sharif Abadi MA, Rouhani Tonekaboni N. [Social support and self-care behaviors in diabetic patients referring to Yazd Diabetes Research Center (Persian)]. Zahadan Journal of Research in Medical Sciences. 2007; 9 (4): 275-84. https://sites.kowsarpub. $\mathrm{com} /$ zjrms/articles/94760.html

[13] Iliaz R, Ozturk GB, Akpinar TS, Tufan A, Sarihan I, Erten N, et al. Approach to pain in the elderly. Journal of Gerontology \& Geriatric Research. 2013; 2(3):e1000125. [DOI:10.4172/2167-7182.1000125]
[14] Kaye AD, Baluch AR, Kaye RJ, Niaz RS, Kaye AJ, Liu H, et al. Geriatric pain management, pharmacological and nonpharmacological considerations. Psychology Neuroscience. 2014; 7(1):15-26. [DOI:10.3922/j.psns.2014.1.04]

[15] Eshaghi SR, Shahsanai A, Mellat Ardakani M. [Assessment of the physical activity of elderly population of Isfahan, Iran (Persian)]. Journl of Isfahan Medical School. 2011; 29(147):939-46. http://jims.mui. ac.ir/index.php/jims/article/view/630

[16] Safarkhanlou H, Rezaei Ghahroodi Z. [Elderly population developments in Iran and worldwide (Persian)]. Statistical Centre of Iran 2017; 5(3):8-16. http://amar.srtc.ac.ir/article-1-298-fa.html

[17] United Nations Publication. Addressing the Challenges of Population Ageing in Asia and the Pacific: Implementation of the Madrid International Plan of Action on Ageing [Internet]. 2017 [Updated 2017 Sep 13]. Available from: https://www.unescap.org/publications/ addressing-challenges-population-ageing-asia-and-pacific-implementation-madrid

[18] Irudaya Rajan S, Sankara Sarma P, Mishra US. Demography of Indian aging, 2001-2051. Journal of Aging \& Social Policy. 2003; 15(2-3):11 30. [DOI:10.1300/J031v15n02_02] [PMID]

[19] Râsânen PM, Kanste O, Elo S, Kyngâs H. Factors associated with the self-care of home-dwelling older people. Journal of Nursing Education and Practice. 2014; 4(8):90-6. [DOI:10.5430/jnep.v4n8p90]

[20] Backman K, Hentinen M. Factors associated with the self care of home-dwelling elderly. Scandinavian Journal of Caring Sciences. 2001 15(3):195-202. [DOI:10.1046/j.1471-6712.2001.00007.x] [PMID]

[21] Bayani AA, Mohammad Koocheky A, Goodarzi H. [The reliability and validity of the satisfaction with life scale (Persian)]. Developmental Psychology (Journal of Iranian Psychologists). 2007; 3(11):259-60. http://jip.azad.ac.ir/article_512406 fa.html

[22] Rosenberg M. Society and the adolescent self-image. Pennsylvania: Diane Publishing Company; 1989. https://books.google.com/books? $d=Y R 3 W C g A A Q B A J \&$ printsec $=$ frontcover $\& d q=$

[23] Barkhordary M, Jalalmanesh S, Mahmodi M. [The relationship between critical thinking disposition and self-esteem in third and fourth year bachelor nursing students (Persian)]. Iranian Journal of Medical Education. 2009; 9(1):13-9. http://ijme.mui.ac.ir/article-1-925-fa. $\mathrm{html}$

[24] Arzani A, Zahedpasha Y, Ahmadpour-Kacho M, Khafri S, Khairkhah $F$, Aziznejad P. [Kangaroo care effect on self-esteem in the mothers of low birth weight infants (Persian)]. Journal of Babol University of Medical Science. 2012; 14(3):52-8. http://jbums.org/article-1-4090-fa.htm

[25] Sharifi Neyestanak ND, Ghodoosi Boroojeni M, Seyedfatemi N, Heydari M, Hoseini AF. [Self-esteem and associated factors in patients with multiple sclerosis (Persian)]. Iran Journal of Nursing. 2012; 25(78):14-22. http://ijn.iums.ac.ir/article-1-1364-fa.htm

[26] Mohammadi N, Sajadinegad M. [The Evaluation of psychometric properties of Body Image Concern Inventory and examination of a model about the relationship between body mass index, body image dissatisfaction and self-esteem in adolescent girls (Persian)]. Quarterly Journal of Psychological Studies. 2007; 1(3):83-99. https://www.sid.ir/ $\mathrm{fa} /$ journal/ViewPaper.aspx?ID=67343

[27] Akhlaghi F, Mokhber N, Shakeri MT, Shamsa F. [Relation between depression, anxiety, self-esteem, marital satisfaction, demographical factor and maternal complications with fear of childbirth in nulliparous women (Persian)]. Journal of Mental Health Principle. 2013 14(2):122-33. [DOI:10.22038/JFMH.2012.982] 
[28] Rajabi GR, Bohlol N. [Self-Esteem Scale reliability and validity assessment in first year students martyr Chamran University (Persian)]. Journal Educational and Psychological Research. 2006; 3(2):33-48. https:// www.sid.ir/fa/journal/ViewPaper.aspx?ID=138197

[29] Zimet GD, Dahlem NW, Zimet SG, Farley GK. The multidimensional scale of perceived social support. Journal of Personality Assessment. 1988; 52(1):30-41. [DOI:10.1207/s15327752jpa5201_2]

[30] Tanjani PT, Azadbakht M. [Psychometric properties of the Persian version of the activities of daily living scale and instrumental activities of daily living scale in elderly (Persian)]. Journal of Mazandaran University of Medical Sciences. 2016; 25(132):103-12. http://jmums.mazums. ac.ir/article-1-6766-fa.html

[31] Farrell J. Nursing care of the older person. Michigan: Lippincott; 1990. https://books.google.vu/books?id=02NsAAAAMAAJ\&dq

[32] Backman K. Self-care of home-dwelling elderly persons from the view of their vulnerability. In: Mičetić-Turk D, Kokol P, editors. International Symposium "New Trends in Modern Nursing". Maribor: University College of Nursing Studies; 2003. pp. 29-34.

[33] Rabiner DJ, Konrad TR, DeFriese GH, Kincade J, Bernard SL, Woomert $A$, et al. Metropolitan versus nonmetropilitan differences in functional status and self-care practice: Findings from a national sample of community-dwelling older adults. The Journal of Rural Health. 1997; 13(1):14-28. [DOI:10.1111/j.1748-0361.1997.tb00830.x] [PMID]

[34] Blair CE. Effect of self-care ADLs on self-esteem of intact nursing home residents. Issues in Mental Health Nursing. 1999; 20(6):559-70. [DOI:10.1080/016128499248367] [PMID]

[35] Lehtola S, Koistinen P, Luukinen $\mathrm{H}$. Falls and injurious falls late in home -dwelling life. Archives of Gerontology and Geriatrics. 2006; 42(2):217-24. [DOI:10.1016/j.archger.2005.07.002] [PMID]

[36] Fialová D, Onder G. Medication errors in elderly people: Contributing factors and future perspectives. British Journal of Clinical Pharmacology. 2009; 67(6):641-5. [DOI:10.1111/j.1365-2125.2009.03419.x] [PMID] [PMCID]

[37] Isola A, Backman K, Voutilainen P, Rautsiala T. Family members' experiences of the quality of geriatric care. Scandinavian Journal of Caring Sciences. 2003; 17(4):399-408. [DOI:10.1046/j.0283-9318.2003.00246.x] [PMID]

[38] Trief PM, Ploutz-Snyder R, Britton KD, Weinstock RS. The relationship between marital quality and adherence to the diabetes care regimen. Annals of Behavioral Medicine. 2004; 27(3):148-54. [DOI:10.1207/ s15324796abm2703_2] [PMID]

[39] Gallagher R, Luttik ML, Jaarsma T. Social support and self-care in heart failure. Journal of Cardiovascular Nursing. 2011; 26(6):439-45. [DOI:10.1097/JCN.0b013e31820984e1] [PMID]

[40] McWilliam CL, Stewart M, Brown JB, McNair S, Donner A, Desai K, et al. Homebased health promotion for chronically ill older persons: Results of a randomized controlled trail of a critical reflection approach. Health Promotion International. 1999; 14(1):27-41. [DOI:10.1093/ heapro/14.1.27]

[41] Li F, Harmer P, Chaumeton NR, Duncan TE, Duncan SC. Tai Chi as a means to enhance self-esteem: A randomized controlled trial. Journal of Applied Gerontology. 2002; 21(1):170-89. [DOI:10.1177/073346480 202100105]

[42] Lantz JM. In search of agents for self-care. Journal of Gerontology Nursing. 1985; 11(7):10-4. [DOI:10.3928/0098-9134-19850701-06] [PMID]
[43] Koirala J, Raddi SA, Shivaswamy MS, Koirala D, Koirala A, Koirala S, Koirala N. The knowledge and practices of self-care capabilities among geriatric population. International Journal of Biochemistry \& Physiology. 2019; 4(1):000144. [DOI:10.23880/ijbp-16000144]

[44] Geboers B, de Winter AF, Spoorenberg SLW, Wynia K, Reijneveld SA. The association between health literacy and self-management abilities in adults aged 75 and older, and its moderators. Quality of Life Research. 2016 25(11):2869-77. [DOI:10.1007/s11136-016-1298-2] [PMID] [PMCID]

[45] Mahdizadeh M, Solhi M. Relationship between self-care behaviors and health literacy among elderly women in Iran, 2015. Electronic Physician. 2018; 10(3):6462-9. [DOI:10.19082/6462] [PMID] [PMCID]

[46] Covinsky KE, Palmer RM, Fortinsky RH, Counsell SR, Stewart AL, Kresevic $D$, et al. Loss of independence in activities of daily living in older adults hospitalized with medical illnesses: Increased vulnerability with age. Journal of the American Geriatrics Society. 2003; 51(4):451-8. [DOI:10.1046/j.1532-5415.2003.51152.x] [PMID]

[47] Bongard V, McDermott AY, Dallal GE, Schaefer EJ. Effects of age and gender on physical performance. Age. 2007; 29(2-3):77-85. [DOI:10.1007/s11357-007-9034-z] [PMID] [PMCID]

[48] Salehi L, Salaki S, Alizadeh L. [Health-related quality of life among elderly Member of elderly centers in Tehran (Persian)]. Iranian Journal of Epidemiology. 2020; 8(1):14-20. http://irje.tums.ac.ir/article1-15-fa.html

[49] Goudarzi H, Salehi L. [Self-care and relevant factors shaping quality of life among the elderly with and without chronic disease (Persian)]. Preventive Care in Nursing \& Midwifery Journal. 2017; 7(2):25-32. http:// zums.ac.ir/nmcjournal/article-1-499-fa.html

[50] Mackinlay E, Trevitt C. Living in aged care: using spiritual reminiscence to enhance meaning in life for those with dementia. International Journal of Mental Health Nursing. 2010; 19(6):394-401. [DOI:10.1111/ j.1447-0349.2010.00684.x] [PMID] 